\title{
Analysis of Development Block Paving with Plastic Waste Material Adhesive Leaves
}

\author{
Supriyadi, Sugiharto, Edy Suhartono, Sukoyo, Dadiyono, Aqqibaini \& Trilaksono \\ Engineering Program Maintenance and Repair Building, Civil Engineering Department \\ State Polytechnic of Semarang \\ Indonesia
}

\begin{abstract}
Plastic waste remains a major problem in Indonesia, however, it's processing and utilization is currently very limited, especially in the construction sector. In addition, they are possibly divided into two categories, which include (1) Plastic garbage, which consists of bottles container for mineral water, soap, and oil, as well as oil conductors, buckets, e.t.c. (2) leaf of plastic waste, encompassing bags, food wrappers, mica snack, e.t.c. Furthermore, one of the famous construction materials is the paving block, used as cover for pavement surfaces, usually characterized by good quality, with high value of compressive strength and low water absorption capacity. This research, therefore, was conducted with experimental methods, using plastic waste leaves as an adhesive in the manufacture of paving blocks with varying mixtures C1 (2 plastic: 1 sand), C2 (3 plastic: 1 sand), C3 (5 plastic: 1 sand), C4 (9 plastic: 1 sand), and C5 (11 plastic: 1 sand). In addition, tests were conducted by the Indonesian National Standard (SNI), and the results showed the optimum mixture was C5 (11 plastic: 1 sand), based on the compressive strength of $246.93 \mathrm{~kg} /$ $\mathrm{cm}^{2}$, and water absorption value of $2.23 \%$. Hence, it is categorized into quality B, which is possibly applied in parking space construction. This, therefore, indicates the capability of applying plastic waste leaves, with a certain mixture variation as an adhesive in the manufacture of paving blocks.
\end{abstract}

Keywords: Paving Block, Waste Plastics, Compressive Strength, Water Absorption.

\section{INTRODUCTION}

Indonesia is the second largest contributor of plastic waste after China, which often those not undergo recycling and processing, therefore, getting carried away by the water current. These, therefore, empty into the open sea, and subsequently accumulate in the ocean, creating dirty sea water that disrupts its ecosystems. In addition, this confers a negative impact in the tourism sector, disrupting the economy in coastal communities. Plastic wastes are goods considered used and discarded by a previous user, which posess the possibility of being managed, through the utility of the the correct procedure (Basriyanta, 2007). Furthermore, they are divided into two categories, which include (1) Hard plastic waste, consisting of cups, bottles, and others. (2) Leaves of Plastic waste, consisting of bags, instant noodles, snack mica, wrap cooking oil and others.

Contemporarily, recycling is the major focus for the hard variety, with a limitation of use for the leaves type. In addition, with the appropriate processing, there is an enhanced possibility of obtaining a high value, one of which is by creating adhesive cement substitutes in the manufacture of paving blocks. These are building material compositions, which comprises of a mixture with Portland cement or other hydraulic adhesive, including water and aggregates, with or without other additives that do not further reduce the quality of SNI 03-0691-1996. Furthermore, various innovations have been made in this direction, including its use as an ingredient, although this technique is considered rare, especially with the leaves variety.

The selected plastic ought to possess high value, in order to promote its use as a substitute for cement adhesive materials, due to the fact that manufacturing process is expected to be easy as a result of the uncomplicated nature of treatment, in comparison with conventional types. 
International Journal of Advances in Scientific Research and Engineering (ijasre),Vol 5 (9), September 2019

\subsection{Formulation of the problem}

a. Common problems

Mixtures of plastic waste have not been used much in the construction sector, therefore, the compressive strength of paving blocks, manufactured using leaves plastic as adhesive are not yet conducted.

b. Special problems

The unknown effects of the compressive strength, as well as the water absorption characteristics demonstrated by the produced paving blocks, according to standards. In this study plastic waste leaves are expected to possess a high value, in order for it to be applied as a substitute to cement adhesive materials in the manufacture of paving blocks. These are needed, due to the fact that it is, because the treatment required is easy, in comparison with the conventional method. No much people have utilized the mixture of plastic waste in the construction sector, and there are no tests based on the compressive strength, which serves as an adhesive in plastic waste leaves.

\section{RESEARCH PURPOSES}

\subsection{General purpose}

This study is expected to show the use of plastic waste leaves as an adhesive in the construction of paving blocks.

\subsection{Special purpose}

This research is meant to predict its compressive strength and water absorption properties.

\section{CONTRIBUTION RESEARCH}

\subsection{For Society / Stakeholders}

This study is expected to provide ideas or innovations to the public, based on the use of plastic waste materials, including reprocessing. This ensures that it does not end up as waste, which consequently undermines and leads to environmental disruption.

\subsection{For Science and technology}

The research outcome is expected to serve as a reference for basic materials, especially plastic waste, based on the observation.

\section{LITERATURE REVIEW}

This study is a combination of previous ones, presented as journals and thesis, subsequently described in a tabular form, as seen in Table 1.

Table 1

Related Journals On Plastic Waste Utilization in the Construction Sector

\begin{tabular}{|c|c|c|c|c|}
\hline No. & Author and Title & Problem & Equation & Difference \\
\hline 1 & $\begin{array}{l}\text { Handayasari I, et al (2018) } \\
\text { "Environmentally Friendly } \\
\text { Construction Materials With } \\
\text { Plastic Bottle Packaging } \\
\text { Waste Utilization of Mineral } \\
\text { and Waste Water Shells Green } \\
\text { For Block Paving Mixture" }\end{array}$ & $\begin{array}{l}\text { Utilization of waste } \\
\text { plastic bottles of mineral } \\
\text { water packaging and } \\
\text { green shells as materials } \\
\text { for block pacing }\end{array}$ & $\begin{array}{l}\text { Sample paving blocks } \\
\text { are made and equally } \\
\text { evaluated using the } \\
\text { pressure and water } \\
\text { absorption test }\end{array}$ & $\begin{array}{l}\text { Waste plastic bottles of } \\
\text { mineral water packaging } \\
\text { and green shells are used } \\
\text { as a mixture for paving } \\
\text { blocks, while the authors } \\
\text { researched on adhesive } \\
\text { materials in the form of } \\
\text { waste leaves. }\end{array}$ \\
\hline 2 & $\begin{array}{l}\text { Amran Joseph (2016) } \\
\text { "Utilization of Waste Plastics } \\
\text { for Supplementary Material as } \\
\text { an Alternative Development } \\
\text { Block Paving Pavement In } \\
\text { Parking Lot At the University } \\
\text { of Muhammadiyah Metro" }\end{array}$ & $\begin{array}{l}\text { Utilization of fiber plastic } \\
\text { bottles as ingredients in } \\
\text { the manufacture of paving } \\
\text { blocks, where it is mixed } \\
\text { with cement, sand, } \\
\text { lubricating oil and water }\end{array}$ & $\begin{array}{l}\text { Preparation of the test } \\
\text { object is equally done by } \\
\text { melting the plastic before } \\
\text { integrating with other } \\
\text { ingredients. }\end{array}$ & $\begin{array}{l}\text { In this research, the } \\
\text { material used was plastic } \\
\text { bottle, while the authors } \\
\text { research on the use of } \\
\text { plastic waste leaves. }\end{array}$ \\
\hline 3 & $\begin{array}{l}\text { Suwarno Anung and } \\
\text { Sudarmono } \\
(2015) \\
\text { "Study of Plastic Waste Usage } \\
\text { For Mixed Concrete } \\
\text { Aggregates" }\end{array}$ & $\begin{array}{l}\text { Waste plastic bags were } \\
\text { used as ingredient in the } \\
\text { manufacture of concrete } \\
\text { with a varied mix ratio }\end{array}$ & $\begin{array}{l}\text { The test specimen } \\
\text { equally involved the use } \\
\text { of garbage plastic bags as } \\
\text { a mixture for paving } \\
\text { blocks. }\end{array}$ & $\begin{array}{l}\text { In this study, the samples } \\
\text { made are tested for tensile } \\
\text { strength, while the } \\
\text { research to be writen } \\
\text { encompasses testing a } \\
\text { sample made for } \\
\text { compressive strength and } \\
\text { water absorption }\end{array}$ \\
\hline
\end{tabular}

Source : Civil Engineering Literature, 2019 


\subsection{Theoretical basis}

\subsubsection{Paving Block}

Based on SNI 03-0691-1996, paving block (concrete brick) is a building material composition, which comprises a mixture of Portland cement or other hydraulic adhesives, water, and aggregates, with or without other additives that are unable of reduce the quality of concrete.

In addition, a good quality is identified by having a high value for strong urge (unit Mpa), and low percentage of water absorption. Regarding standards, the characteristic quality were shown to be better, based on the presentation of a strong urge, while a lesser superiority is observed in percentage of water uptake. Therefore, an elevation in strength value provides a guide to the preferred paving block, and a lower percentage of absorption value indicates a stronger product.

Paving Block by SNI 03-0691-1996 are expected to meet the quality requirements seen in the natural looks, size, and physical properties, although they are also classified by shape, strength, thickness, and color.

\subsubsection{Aggregate}

Fine aggregate was used in this study as a filler material between the coarse aggregate, creating a stronger bond of BJ 1400 $\mathrm{kg} / \mathrm{m}$, with sludge value less than $5 \%$ of the weight, or the absence of organic material, consisting of sharp, hard, and varied grains. Based on SNI 03-6820-2002, their maximum grain size is $4.76 \mathrm{~mm}$ from natural products, while refined ones are obtained from fractions and separation by filtering or other means, including rock or slag blast furnace.

\subsubsection{Trash Plsatic Leaves}

Plastic waste are goods considered as used, and subsequently discarded by the previous owner. These are probably recyclable if properly managed, and they are, further, divided into two types, including (1) hard plastic waste, which consists of plastic bottles, glass, and other atoms, and (2) plastic leaves, encompassing garbage bag, instant noodles, snack mica, wrap cooking oil, etc.

\subsection{Research Methods}

Broadly speaking, the data investigated involves studying the characteristics of fine aggregate, including paving block compressive strength, and its water absorption. Meanwhile, the technique adopted requires observing the test characteristics, with the following research stages:

\subsubsection{Preparation phase}

1. Study of literature

2. Conduction of reference search and related researches.

3. Variation Mix planning

4. Fluctuating the mixture used in the manufacture of test specimens, predetermined according to the number created

5. Preparing the Equipment and Materials for Test.

6. Evaluate the fine aggregates at the Laboratory Materials Semarang State Polytechnic.

\subsubsection{Implementation phase}

1. Testing the Physical Characteristics of Fine Aggregate

Testing the physical characteristics of fine aggregate made involves the evaluation of their organic content, encompassing a grain level assessment, which was conducted through the filter 200, analysis for seive, gravity, and moisture content. In addition, all tests were performed using the appropriate method listed in the Indonesian National Standard (SNI).

\section{Preparation of Test Objects}

After obtaining a fine aggregate for use as an ingredient in the manufacture of paving blocks, the next step entails:

a. $\quad$ Setting up the building paving blocks

The materials used in the manufacture of paving blocks test specimen were plastic waste leaves and sand. Meanwhile, prior to this, both were first weighed according to the requirement in each variation mix, and later placed inside a plastic bag. This was conducted in order to facilitate the process.

b. $\quad$ Preparing mold

The hexagonal-shaped molds were wetted with water prior to use, in order for the finished product to be removed with ease from the prints.

c. Creating Test Objects involves

1) Inserting the weighed plastic portion in accordance with the variating combustion mixtures, into the vat.

2) This is then melted in a barrel with fire.

3) Regularly put down little of the remaining plastics into a vat containing the burned ones, and control the fire to remain ignited up to when the entire melt occur.

4) Enter the weighed sand mix to the point where it is well blended.

5) Set up a paving block mold moistened with water. 
6) Pour batter consisting of melted plastic with sand into it.

7) Measure the temperature at the time of dough in a print, through the use of a thermometer.

8) Press into the mold with force.

9) Submerge the entire mold and mixture into water for \pm 10 minutes.

10) Remove the specimen from the mold.

11) Tidy up the sides, using a machete, in order to make neat.

The above steps are taken on each variation of the mixture, with 3 specimens, and similar steps were performed with the same amount of test objects.

d. Compressive Strength Testing Phase Block Paving

Paving block compressive strength testing is conducted through the following steps:

1) Cut the hexagonal-shaped specimen into cubes (with size $5 \times 5 \times 5 \mathrm{~cm}$ ), using special concrete cutting tools.

2) Measure the dimensions (length, width, height) cut using a caliper, and note the results into a created table.

3) Evaluate the weight of each specimen using the scales, and record.

4) Place the test object in press tools.

5) Perform loading up to the crack or breaking point, because of its plastic source.

6) Record the maximum load retained.

7) Calculate the compressive strength generated.

e. Water Absorption Test Phase Paving Block

Testing the water absorption block paving was performed using the following steps:

1) Submerge the hexagonal-shaped specimen into water for \pm 24 hours.

2) Measure the weight of the specimen using the scales in a wet state, and subsequently noting the results.

3) Dry in a conditioned room or kitchen for \pm 24 hours.

4) Measure the weight of the dried specimen by using a scale.

f. Stage Analysis Data

1) Characteristics of Fine Aggregate Testing

The characteristics data of fine aggregates, recorded and placed in a table were analyzed using a formula on each.

2) Compressive Strength Testing Block Paving

After examining the compressive strength, the data obtained were analyzed using several methods, programs or applications. In addition, the program used was Ms.Excel and one way ANOVA method, using the Statistical Package for the Social Sciences (SPSS).

3) Testing Water Absorption Block Paving

Data from water absorption test were processed using Ms.Excel program, with the creation of tables with results. This contains a mixture of variety, size, basal area, dry weight, the weight after immersion and suction. In addition, the software is also used to create graphs and histograms, which explicitly show variations. Furthermore, it was chosen as a result of its stress-free operation, in order to enhance the ease of determining the effect of variations in the mixture against water absorption.

\section{RESULTS AND DISCUSSION}

\subsection{Materials Materials Testing Results}

Test of Muntilan Sand was conducted prior to the use of fine aggregates as a mixture for paving blocks. This was conducted to obtain a combination of materials that meet the specifications, which is in accordance with the SNI. Table 2 shows the test results of the physical properties of fine aggregate sand.

Table 2

Physical Properties Testing Results Summary Fine Aggregate

\begin{tabular}{|c|c|c|c|c|c|c|}
\hline \multirow{2}{*}{ No. } & \multirow{2}{*}{ types of Tests } & \multirow{2}{*}{ Testing methods } & \multirow{2}{*}{ Test results } & \multicolumn{2}{|c|}{ Specification } & \multirow{2}{*}{ Uni } \\
\hline & & & & Min & Max & \\
\hline 1. & Organic Content & ISO 2816: 2014 & Younger & - & - & $\%$ \\
\hline 2. & $\begin{array}{l}\text { Fine Grain Levels Through } \\
\text { Sieve } 200\end{array}$ & SNI 03-4142-1996 & 11.92 & - & 5 & $\%$ \\
\hline 3. & Density of Fine Aggregate & SNI 03-1970-1990 & 2,679 & - & - & $\%$ \\
\hline 4. & Fine Aggregate Water Content & SNI 03-1971-1990 & 4.72 & - & 2,14 & $\%$ \\
\hline 5. & Sieve analysis & SNI 03-1968-1990 & 3,009 & 1.5 & 3.8 & $\%$ \\
\hline
\end{tabular}

Source : Civil Engineering Literature, 2019 
5.2. Compressive Strength Testing Results Paving Block

From compressive strength testing, the fifth-mix paving block of mixture C1 s / d C5 respectively totaled 3 pieces, indiating an average value as shown in Table 3 below:

Table 3

Average Compressive Strength Mix Paving Block C1 to C5

\begin{tabular}{|c|c|c|c|c|c|c|c|c|c|}
\hline \multirow{2}{*}{ No. } & \multirow{2}{*}{$\begin{array}{c}\text { Comparison of } \\
\text { Mixed }\end{array}$} & \multicolumn{3}{|c|}{ Test object size } & \multirow{2}{*}{$\begin{array}{l}\text { Large } \\
\left(\mathbf{C m}^{2}\right) \\
\end{array}$} & \multirow{2}{*}{$\begin{array}{c}\text { Weight } \\
\text { (G) }\end{array}$} & \multirow{2}{*}{$\begin{array}{c}\text { Maximum } \\
\text { Load Weight } \\
(\mathrm{Kg})\end{array}$} & \multirow{2}{*}{$\begin{array}{l}\text { Compressive } \\
\text { Strength } \\
\left(\mathrm{Kg} / \mathrm{cm}^{2}\right)\end{array}$} & \multirow{2}{*}{$\begin{array}{c}\text { Average } \\
\text { Compressive } \\
\text { Strength } \\
\left(\mathrm{Kg} / \mathrm{cm}^{2}\right)\end{array}$} \\
\hline & & $\mathbf{L}$ & $\mathbf{W}$ & H & & & & & \\
\hline \multirow{3}{*}{$\mathrm{C} 1$} & \multirow{3}{*}{2 Plastic: 1Sand } & 5.63 & 5.12 & 5.09 & 28.83 & 166.79 & 3800 & 131.80 & \multirow{3}{*}{131.32} \\
\hline & & 5.61 & 5.10 & 5.16 & 28.61 & 173.19 & 3400 & 115.76 & \\
\hline & & 5.51 & 5.33 & 4.86 & 29.37 & 146.27 & 4300 & 146.40 & \\
\hline \multirow{3}{*}{$\mathrm{C} 2$} & \multirow{3}{*}{3 Plastic: 1Sand } & 5.10 & 5.37 & 3.96 & 27.39 & 93.27 & 4700 & 171.61 & \multirow{3}{*}{168.8} \\
\hline & & 5.10 & 5.48 & 3.88 & 27.95 & 101.34 & 4700 & 168.17 & \\
\hline & & 5.14 & 5.37 & 4.86 & 27.60 & 116.32 & 4600 & 166.66 & \\
\hline \multirow{3}{*}{$\mathrm{C} 3$} & \multirow{3}{*}{5 Plastic: 1Sand } & 5.50 & 5.66 & 4.98 & 31.13 & 166.06 & 5200 & 167.04 & \multirow{3}{*}{170.56} \\
\hline & & 5.57 & 5.20 & 5.04 & 28.97 & 159.68 & 5100 & 176.04 & \\
\hline & & 5.84 & 5.28 & 5.50 & 30.84 & 161.30 & 5200 & 168.61 & \\
\hline \multirow{3}{*}{$\mathrm{C} 4$} & \multirow{3}{*}{9 Plastic: 1Sand } & 5.48 & 5.50 & 4.16 & 30.14 & 107.59 & 5900 & 195.75 & \multirow{3}{*}{185.30} \\
\hline & & 5.37 & 5.39 & 4.10 & 28.94 & 109.61 & 5000 & 172.77 & \\
\hline & & 5.36 & 5.23 & 4.16 & 28.03 & 114.10 & 5000 & 178.38 & \\
\hline \multirow{3}{*}{$\mathrm{C} 5$} & \multirow{3}{*}{ 11Plastic: 1Sand } & 5.48 & 5.24 & 4.94 & 28.71 & 129.14 & 7400 & 257.75 & \multirow{3}{*}{246.93} \\
\hline & & 5.36 & 5.56 & 5.14 & 29.80 & 144.55 & 8000 & 268.45 & \\
\hline & & 5.38 & 5.37 & 4.90 & 28.89 & 130.02 & 6200 & 214.60 & \\
\hline
\end{tabular}

Source : Civil Engineering Laboratory,201

\subsection{Testing Results Water Absorption Block Paving}

The paving block was tested for water absorption by soaking for 24 hours, and the results obtained are shown in Table 4 below:

Table 4

Testing Results Water Absorption Block Paving

\begin{tabular}{|c|c|c|c|c|c|c|c|}
\hline \multirow[b]{2}{*}{ No. } & \multirow[b]{2}{*}{$\begin{array}{c}\text { comparison of } \\
\text { Mixed }\end{array}$} & \multicolumn{2}{|c|}{ Size (dm) } & \multirow{2}{*}{$\begin{array}{c}\text { Primary } \\
\text { Sector } \\
\text { Size } \\
\left(\mathbf{d m}^{2}\right) \\
\end{array}$} & \multirow[b]{2}{*}{$\begin{array}{c}\text { A Dry } \\
\text { Weight (g) }\end{array}$} & \multirow[b]{2}{*}{$\begin{array}{c}\text { After Soaked } \\
\text { weight (g) }\end{array}$} & \multirow[b]{2}{*}{ Suction Rate } \\
\hline & & Side & Coefficient & & & & \\
\hline $\mathrm{C} 1$ & 2 Plastic: 1Sand & 1.1 & 2,598 & 3.14 & 1918 & 1923 & 1.59 \\
\hline $\mathrm{C} 2$ & 3 Plastic: 1Sand & 1.1 & 2,598 & 3.14 & 1538 & 1545 & 2.23 \\
\hline $\mathrm{C} 3$ & 5 Plastic: 1Sand & 1.1 & 2,598 & 3.14 & 1670 & 1675 & 1.59 \\
\hline $\mathrm{C} 4$ & 9 Plastic: 1Sand & 1.1 & 2,598 & 3.14 & 1587 & 1591 & 1.27 \\
\hline $\mathrm{C} 5$ & 11Plastic: 1Sand & 1.1 & 2,598 & 3.14 & 1511 & 1518 & 2.23 \\
\hline \multicolumn{7}{|c|}{ Suction Rate Average (g/ $\left.\mathrm{dm}^{2} / \mathrm{min}\right)$} & 1,782 \\
\hline
\end{tabular}

Source : Civil Engineering Laboratory, 2019 
International Journal of Advances in Scientific Research and Engineering (ijasre),Vol 5 (9), September 2019

\subsection{Compressive Strength Analysis Block Paving Method Using One Way ANOVA}

After obtaining the compressive strength, each data is processed using one-way ANOVA, and the results are shown in Table 5 below:

Table 5

ANOVA analysis results Compressive Strength Block Paving

\begin{tabular}{cccccc}
\hline & $\begin{array}{c}\text { Sum of } \\
\text { Squares }\end{array}$ & df & $\begin{array}{c}\text { mean } \\
\text { Square }\end{array}$ & F & Sig. \\
\hline $\begin{array}{c}\text { Between } \\
\text { Groups } \\
\text { Within }\end{array}$ & 21207.884 & 4 & 5301.971 & 21.717 & 0,000 \\
$\begin{array}{c}\text { Groups } \\
\text { Total }\end{array}$ & 2441.347 & 10 & 244.135 & & \\
\hline
\end{tabular}

Source : Civil Engineering Literature, 2019

Based on the values obtained in Table 5 the following were hypothesized:

a. Sig value $<0.05$, then Ho is rejected, therefore, the average value of the compressive strength of the paving blocks are of different mixtures.

b. Sig value $>0.05$, then Ho is accepted, which means the average value of compressive strength is relatively the same.

\section{CONCLUSION}

From the results, discussion, the following conclusions were obtained:

1. The influence of replacing the adhesive cement with the plastic waste leaves demonstrated an increase in compressive strength, with an elevation in the number of waste material used.

2. Using one-way ANOVA and subsequently processing with the program Statistical Package for the Social Sciences (SPSS), the compressive strength press paving block C2 (3 plastic: 1 sand), C3 (5 plastic: 1 sand) and C4 (9 plastic: 1 sand) possessed a compressive strength value that was relatively the same. However, C1 (2 plastic: 1 sand) to C5 (11 plastic: 1 sand) were also similar.

3. In addition, paving blocks C5 (11 plastic: 1 sand) had a compressive strength that was most different from others, based on its average value of $246.93 \mathrm{Kg} / \mathrm{cm}^{2}$. Meanwhile, C1 (2 plastic: 1 sand) had the lowest value of $131.32 \mathrm{~kg} / \mathrm{cm}^{2}$.

4. Therefore, paving block C5 was the most optimum of all plastic, at a ratio of 11: 1 to sand. In addition, it was chosen in accordance with the standards set on SNI 03-0349-1989, based on its value of $246.93 \mathrm{~kg} / \mathrm{cm}^{2}$, and water absorption (2.23\%), which was less than $10 \%$

5. Based on SNI 03-0691-1996, C5 is classified as quality B, with a compressive strength equal to $24.22 \mathrm{MPa}$, and water absorption less than $6 \%$, thus it is possibly applied in parking space construction.

6. In terms of cost, plastic paving blocks tend to have a higher selling price in comparison with the conventional types. Meanwhile, in terms of the manufacturing time, they do require a shorter period. This was caused by the process and nature of materials used.

7. The basic ingredients were plastic leaf litter, made into solid blocks, thus, simplifying the treatment procedure and storage.

\section{SUGGESTION}

The study provides information on the use of plastic waste leaves as an adhesive in the manufacture of paving blocks, which is beneficial to manufacturers. Therefore, the following suggestions were communicated:

1. There is the need to increase number of samples in each variation of mix, in order to obtain more accurate results of compressive strength.

2. Extra attention ought to be attributed to the characteristics of the fine aggregate used, in accordance with the Indonesian National Standard (SNI), which has already been set.

3. In the process of making paving blocks, more attention needs to be channeled towards the mixing process. Thus, the mixture is made homogeneous, in order for the products to have good quality.

4. There is also need for further research in making blocks of plastic waste leaves with a mixture of other fine aggregates.

5. Furthermore it is recommended to carry out the level of toxicity of the hazardous and toxic material.

\section{BIBLIOGRAPHY}

1. Amran, Y. 2016. Utilization of Waste Plastics for Supplementary Material as an Alternative Development Block Paving Pavement In Parking Lot At Metro.Google Muhammadiyah University Scholar. Volume 4. 
International Journal of Advances in Scientific Research and Engineering (ijasre),Vol 5 (9), September 2019

2. Anonymous. 1989, SNI 03-0692-1989. Concrete brick To Floor. National Standardization Agency.

3. Anonymous. 1996, SNI 03-0691-1996. Concrete brick (Paving Block). National Standardization Agency.

4. Anonymous. 2002, SNI 03-6820-2002. Specifications Fine Aggregate Mortar And Stucco To Work With Basic Materials Cement. National Standardization Agency.

5. Anonymous. 2002, SNI 03-6861-2002. Non Metallic Building Material Specifications. National Standardization Agency.

6. Anonymous. 2014, ISO 2816: 2014. Test Methods of Organic Materials in Fine Aggregate For Concrete. National Standardization Agency.

7. Arikunto, Suharmini, Prof. Dr. 1998. Research A Practice Approach Procedures (Revised Edition IV). Yogyakarta: Rineka Reserved.

8. Basriyanta. 2007. Harvesting Trash. Yogyakarta: Canisius

9. Budi S. N and Y. Ramadhiansyah 2018. Utilization of Waste Plastic Bottles For Making Mixed brick With Compressive Strength Test (Final). State Polytechnic of Semarang, Semarang.

10. Handayasari. I, Artiani. G. P, and Princess. D. 2018. Sustainable Construction Materials With Plastic Bottle Packaging Waste Utilization of Mineral Water And Waste Shells Green For Block Paving Mixture. Google Scholar. Vol.9, No.2: 2530.

11. Sugiyono, Dr. 2002. Statistics For Research. Bandung: PT. Alfabeta.

12. Suwarno, A and Sudarmono. 2015 Study of Use of Waste Plastics For Mixed Concrete Aggregates. Forum for the Civil Engineering. Vol.20, No.1, pp.1-10. 